удК 631.527:633.2:551.581.21

https://doi.org/10.32634/0869-8155-2021-351-7-8-93-96

Оригинальное исследование/Original research

Павлова С.A.,

Пестерева Е.C.

Якутский научно-исследовательский институт сельского хозяйства им. М. Г. Сафронова ФГБУН ФИЦ ЯНЦ СО РАН, 677001, Республика Саха (Якутия), г. Якутск, ул. Бестужева-Марлинского 23/1

E-mail: Lena79pestereva@mail.ru

Ключевые слова: травостой, смеси, многолетние травы, зеленая масса, урожайность, качество, зеленый конвейер

Для цитирования: Павлова С.А., Пестерева Е.С. Организация зеленого конвейера из районированных многолетних трав в условиях Крайнего Севера. Аграрная наука. 2021; 351 (7-8): 93-96.

https://doi.org/10.32634/0869-8155-2021-351-7-8-93-96

Конфликт интересов отсутствует

Sakhayana A. Pavlova,

Elena S. Pestereva

Yakut Scientific Research Institute of Agriculture named after M.G. Safronov, 23/1 BestuzhevMarlinskogo st., Yakutsk, 677001, Republic of Sakha (Yakutia)

E-mail: Lena79pestereva@mail.ru

Key words: herbage, mixtures, perennial grasses, green mass, yield, quality, green conveyor

For citation: Pavlova S.A., Pestereva E.S Organization of a green conveyor of zoned perennial grasses in the Far North. Agrarian Science. 2021; 351 (7-8): 93-96. (In Russ.)

https://doi.org/10.32634/0869-8155-2021-351-7-8-93-96

There is no conflict of interests

Организация зеленого конвейера из районированных многолетних трав в условиях Крайнего Севера

\title{
РЕЗЮME
}

Актуальность. Цель работы - создание зеленого конвейера из многолетних районированных трав на пойменных лугах. Впервые в условиях Крайнего Севера на основании полевого экспериментального опыта изучен видовой состав и режим использования многолетних злаковых и бобовых трав для организации зеленого конвейера.

Методы. Исследования проводили в 2018-2020 гг. в полевых условиях на опытном поле лаборатории кормопроизводства ФГБУН ЯНИИСХ им. М.Г. Сафронова Хангаласского улуса Республики Саха (Якутия). Почва опытного участка- мерзлотная пойменная дерновая легкосуглинистая. Посев проведен летним сроком в первой декаде июля.

Результаты. В статье включены данные урожайности, химического состава и питательной ценности, экономической эффективности многолетних трав. За годы исследований максимальная урожайность получена из злаковых травосмесей кострец (20)+ п ырейник (16) - 4,0 т/га зеленой массы, что выше естественного травостоя на 2,4 т/га зеленой массы. Урожайность чистого посева люцерны серповидной (8 кг/га) составила 4,5 т/га зеленой массы. Максимальную урожайность из бобово-злаковых травосмесей обеспечила двухкомпонентная смесь люцерна (8к г/га) + кострец (10 кг/га) - 4,9 т/га зеленой массы. Наиболее высокое содержание сырого протеина при создании зеленого конвейера из одновидовых злаковых посевов отмечается у овсяницы красной - 18,2\%, при этом содержание обменной энергии - 9,1 МДж, кормовых единиц - 0,66, переваримого протеина - 122 г в 1 кг сухого вещества. Из бобово-злаковых травостоев наибольшее содержание сырого протеина обеспечивает люцерна (8к г/га) - 19,0\%, при этом содержание обменной энергии - 9,3 МДж, кормовых единиц - 0,70, переваримого протеина - 120 г в 1 кг сухого вещества. При создании зеленого конвейера из злаковых травостоевполучен высокий условно-чистый доход при посеве костреца безостого (20 кг/га) +п ырейника (16 кг/га) - 5688 руб./га, при этом стоимость продукции - 12000 руб./га, рентабельность - 90\%.

\section{Organization of a green conveyor of zoned perennial grasses in the Far North}

\section{ABSTRACT}

Relevance. The aim of the work is to create a green conveyor belt of perennial zoned grasses in floodplain meadows. For the first time in the Far North on the basis of field experience were studied species composition and mode of use of perennial grasses and legumes for green belt.

Methods. The research was conducted in 2018-2020 in field conditions in the experimental field laboratory of horticulture of Yakut Scientific Research Institute of Agriculture named after M.G. Safronov in the Khangalassky ulus of the Sakha Republic (Yakutia). The soil of the experimental site is permafrost floodplain turf light loamy. Sowing was carried out in summer in the first decade of July.

Results. The article includes data on the yield, chemical composition and nutritional value, and economic efficiency of perennial grasses. Over the years of research, the maximum yield was obtained from the grass mixtures of rumps (20)+ wheatgrass (16) $4.0 \mathrm{t} / \mathrm{ha}$ of green mass, which is higher than the natural herbage by $2.4 \mathrm{t} / \mathrm{ha}$ of green mass. The yield of net sowing of sickle alfalfa ( $8 \mathrm{~kg} / \mathrm{ha}$ ) was $4.5 \mathrm{t} / \mathrm{ha}$ of green mass. The maximum yield from leguminous grass mixtures was provided by a two-component mixture of alfalfa $(8 \mathrm{~kg} / \mathrm{ha})+$ stalk $(10 \mathrm{~kg} / \mathrm{ha})-4.9 \mathrm{t} / \mathrm{ha}$ of green mass. The highest content of crude protein when creating a green conveyor from single-species cereal crops is observed in red oatmeal $-18.2 \%$, while the content of exchange energy is $9.1 \mathrm{MJ}$, feed units -0.66 , digestible protein $-122 \mathrm{~g}$ in $1 \mathrm{~kg}$ of dry matter. Of legumes and cereals the highest content of raw protein is provided by alfalfa ( $8 \mathrm{~kg} / \mathrm{ha})-19.0 \%$, while the content of exchange energy is $9.3 \mathrm{MJ}$, feed units -0.70 , digestible protein is $120 \mathrm{~g}$ per $1 \mathrm{~kg}$ of dry matter. When creating a green conveyor from grass stands, a high conditional net income is obtained when sowing boneless stalk (20 kg/ha) +w heatgrass (16 kg/ha) -5688 rubles/ha, while the cost of production is 12,000 rubles/ha, the profitability is $90 \%$.

Поступила: 21 февраля

После доработки: 30 мая

Принята к публикации: 10 сентября
Received: 21 February

Revised: 30 May

Accepted: 10 september 


\section{Введение}

В Республике Саха (Якутия) основным направлением сельского хозяйства является животноводство. 1 января 2020 г. в хозяйствах всех категорий поголовье лошадей составило 184 тыс. голов, крупного рогатого скота -183 тыс. голов, из них коров -70 тыс. голов. Животноводство Республики Саха характеризуется низкой продуктивностью. В связи с развитием в республике северного животноводства поднимается вопрос обязательного опережающего развития полевого и лугового кормопроизводства. Генетический потенциал продуктивности скота в условиях Севера на $70 \%$ определяется кормлением, остальные $30 \%$ - технология и селекция. В РС (Я) имеется достаточно сельхозугодий для производства до 50-55 тыс. тонн мяса и до 220 тыс. тонн молока и обеспечения потребным количеством кормов - сена (до 600 тыс. тонн), силоса (60 тыс. тонн), сенажа (50 тыс. тонн) [1].

По республике в среднем за 2016-2020 гг. заготовлено 468,2 тыс. тонн сена, из них наибольшее количество сена заготовлено в 2017 г. - 472,6 тыс. тонн, наименьшее - в 2016 г. - 457,3 тыс. тонн. Все это говорит о том, что объемы заготовки сена полностью зависят от погодных условий года. Значительные площади отдаленных сенокосных угодий заброшены из-за слабой материально-технической базы, отсутствия достаточных финансовых средств у хозяйств, поэтому население их не использует [2]. В последние годы наблюдается сильное вырождение близлежащих естественных сенокосов и пастбищ из-за повышенной скотоемкости, конеемкости, нарушения сенокосооборота, бессистемной пастьбы скота в период отрастания трав весной и осенью, что приводит к резкому снижению урожайности естественных лугопастбищных угодий.

Для правильного решения вопроса о подборе многолетних трав как компонентов зеленого конвейера большое значение имеет изучение особенностей растений и, прежде всего, продуктивности зеленой массы и длительности вегетационного периода [3]. Известно, что злаковые травы животные охотно поедают с начала выхода растений в трубку до колошения. Бобовые растения лучше поедаются с начала стеблевания до конца бутонизации - начала цветения $[4,5]$. Цель работы создание зеленого конвейера из многолетних районированных трав на пойменных лугах.

\section{Методика исследований}

Исследования проводили в 2018-2020 гг. в полевых условиях на опытном поле лаборатории кормопроизводства ФГБУН Якутского НИИ сельского хозяйства имени М.Г. Сафронова Хангаласского улуса Республики Саха (Якутия). Посев многолетних трав из районированных сортов для создания зеленого конвейера проведен летним сроком. Площадь делянок $-100 \mathrm{~m}^{2}$, в четырехкратной повторности, размещение рендомизированное. Минеральные удобрения вносили весной в дозе $(\mathrm{NPK})_{60}$. Объект исследований - кострец безостый сорт Хаптагайский, пырейник сибирский - сорт Амгинский, овсяница красная - сорт Мюрюнская, донник белый - сорт Немюгюнский.

Схема опыта: злаковые травостои: 1 - естественный травостой - контроль, 2 - кострец безостый, 3 - пырейник сибирский, 4 - овсяница красная, 5 кострец безостый + пырейник сибирский, 6 - кострец безостый + овсяница красная, 7 - кострец безостый + пырейник сибирский + овсяница красная; бобово-злаковые травостои: 1 - люцерна серповидная,
2 - донник белый, 3 - люцерна + кострец безостый, 4 - люцерна + кострец безостый + донник белый, $5-$ люцерна + пырейник сибирский + донник белый, $6-$ люцерна + кострец безостый + донник белый + пырейник сибирский, 7 - люцерна + кострец безостый + донник белый + пырейник сибирский + овсяница. Почва - мерзлотная пойменная дерновая легкосуглинистая с содержанием гумуса в слое $0-30$ см $-5,4 \%$, общего азота - 0,38\%, обеспеченность подвижным фосфором - 323 мг/кг почвы, обменным калием $161 \mathrm{мг/кг} \mathrm{почвы,} \mathrm{рН} \mathrm{солевой} \mathrm{вытяжки} \mathrm{-} \mathrm{7,6.} \mathrm{Исполь-}$ зовались районированные сорта местной Якутской селекции. Технология возделывания трав общепринятая согласно зональной системе Республики Саха (Якутия) [6].

Учеты и наблюдения проводились по общепринятым методикам ВНИИ кормов [7] и согласно Методическому пособию по агроэнергетической и экономической оценке технологий и систем кормопроизводства [8]. Агрохимические анализы пахотного слоя почвы и химический состав кормов проведены в лаборатории переработки сельскохозяйственной продукции и биохимических анализов ЯНИИСХ на анализаторе SpectraStar 2200. Статистическая обработка данных проводилась по Б.А. Доспехову [9].

\section{Результаты исследований}

Для правильного решения вопроса о подборе культур многолетних трав как компонентов зеленого конвейера большое значение имеет изучение особенностей растений и, прежде всего, продуктивности зеленой массы и длительности вегетационного периода [10]. Возделывание многолетних трав для создания зеленого конвейера на пойменных лугах показало, что урожайность и видовой состав сеяных злаковых и бобово-злаковых травостоев зависели от биологических особенностей изучаемых видов трав и их смесей.

При организации зеленого конвейера из одновидовых злаковых многолетних трав максимальную урожайность обеспечил кострец безостый (20 кг/ га) - 3,5 т/га, из бобово-злаковых - люцерна желтая сорта Якутская (8 кг/га) - 4,5 т/га зеленой массы. Из двухкомпонентных смесей злаковой травосмеси максимальную урожайность получили у костреца (20) + пырейника (16) - 4,0 т/га. Из злаково-бобовых травостоев высокую урожайность обеспечила двухкомпонентная смесь люцерна (8к г/га) + кострец (10 кг/га) - 4,9 т/га зеленой массы. Высокую урожайность сформировала многокомпонентная травосмесь люцерна (2) + кострец (5)+ д онник+ п ырейник( 4)+ о всяница $-4,6$ т/га. Низкой урожайностью отмечается естественный травостой (контроль) - 1,6 т/га, среди изучаемых сеяных злаковых трав - пырейник сибирский (16) - 2,8 т/га, из злаково-бобовых - травосмесь люцерна (6)+ пырейник (12) + донник белый - 3,9 т/га. Таким образом, за годы исследований максимальная урожайность получена из злаковых травосмесей укостреца (20) + пырейника (16) - 4,0 т/га зеленой массы, что выше естественного травостоя на 2,4 т/га зеленой массы. Урожайность чистого посева люцерны серповидной (8 кг/га) составила 4,5 т/га зеленой массы. Максимальную урожайность из бобово-злаковых травосмесей обеспечила двухкомпонентная смесь люцерна (8 кг/га) + кострец (10 кг/га) - 4,9 т/га зеленой массы (табл. 1).

Анализ ботанического состава злаковой смеси показал, что основу травостоя составили сеяные виды 
Таблица 1. Урожайность и видовой состав злаковых и бобово-злаковых травостоев для создания зеленого конвейера (среднее за 2018-2020 гг.)

Table 1. Yield and species composition of cereals and legumes for creating a green conveyor belt (average for 2018-2020)

\begin{tabular}{|c|c|c|c|c|c|c|c|}
\hline \multirow{2}{*}{$\begin{array}{l}\text { Видовой состав травосмесей (норма высева, } \\
\text { кг/га) }\end{array}$} & \multirow{2}{*}{$\begin{array}{c}\text { Урожайность } \\
\text { зеленой массы, } \\
\text { т/га }\end{array}$} & \multicolumn{5}{|c|}{ Массовая доля, \% } & \multirow{2}{*}{ Разнотравье } \\
\hline & & \multicolumn{2}{|c|}{ кострец безостый } & пырейник & \multicolumn{2}{|c|}{ овсяница красная } & \\
\hline \multicolumn{8}{|c|}{ Злаковые травосмеси } \\
\hline 1. Естественный травостой & 1,6 & \multicolumn{2}{|l|}{-} & - & \multicolumn{2}{|l|}{-} & 100 \\
\hline 2. Кострец безостый (20) & 3,5 & \multicolumn{2}{|c|}{92,0} & - & \multicolumn{2}{|l|}{-} & 8,0 \\
\hline 3. Пырейник сибирский (16) & 2,8 & \multicolumn{2}{|l|}{-} & 57,5 & \multicolumn{2}{|l|}{-} & 42,5 \\
\hline 4. Овсяница красная & 3,3 & \multicolumn{2}{|l|}{-} & & \multicolumn{2}{|c|}{92,5} & 7,5 \\
\hline 5. Кострец (20) + пырейник (16) & 4,0 & \multicolumn{2}{|c|}{53,0} & 23,5 & \multicolumn{2}{|l|}{-} & 23,5 \\
\hline 6. Кострец (15) + овсяница (12) & 3,8 & \multicolumn{2}{|c|}{55,5} & - & \multicolumn{2}{|c|}{33,0} & 11,5 \\
\hline $\begin{array}{l}\text { 7. Кострец + (10) + пырейник( 8) +o } \\
\text { всяница( 8) }\end{array}$ & 3,8 & \multicolumn{2}{|c|}{52,0} & 12,05 & \multicolumn{2}{|c|}{22,0} & 13,9 \\
\hline $\mathrm{HCP}_{05}$ & 1,7 & & & & & & \\
\hline \multicolumn{8}{|c|}{ Злаково-бобовые травосмеси } \\
\hline $\begin{array}{l}\text { Видовой состав травосмесей (норма высева, } \\
\text { кг/га) }\end{array}$ & $\begin{array}{c}\text { Урожайность } \\
\text { зеленой массы, } \\
\text { т/га }\end{array}$ & $\begin{array}{l}\text { Кострец } \\
\text { безостый }\end{array}$ & Пырейник & Люцерна & Донник белый & Овсяница & Разнотравье \\
\hline 1. Люцерна (8 кг/га) & 4,5 & - & - & 93,8 & - & - & 6,15 \\
\hline 2. Донник белый (12 кг/га) & & - & - & & - & - & \\
\hline $\begin{array}{l}\text { 3. Люцерна (8 кг/га) + кострец (20 кг/ } \\
\text { га) }\end{array}$ & 4,9 & 43,4 & - & 49 & - & - & 7,55 \\
\hline $\begin{array}{l}\text { 4. Люцерна( 6)+ к острец( 15)+ д онник } \\
\text { белый }\end{array}$ & 4,0 & 45,5 & - & 49,5 & - & - & 4,95 \\
\hline $\begin{array}{l}\text { 5.Люцерна (6)+ п ырейник (12)+ д онник } \\
\text { белый }\end{array}$ & 3,9 & - & 17,6 & 65,5 & - & - & 16,8 \\
\hline $\begin{array}{l}\text { 6. Люцерна( 4)+ кострец (10)+ донник+ } \\
\text { п ырейник (8) }\end{array}$ & 4,5 & 38,5 & 12,0 & 39,6 & - & - & 9,8 \\
\hline $\begin{array}{l}\text { 7. Люцерна (2)+ к острец (5)+ донник+ п } \\
\text { ырейник (4)+ о всяница }\end{array}$ & 4,6 & 32,1 & 10,6 & 36,5 & - & 12,0 & 8,65 \\
\hline $\mathrm{HCP}_{05}$ & 2,3 & & & & & & \\
\hline
\end{tabular}

как зимостойкие, засухо- и солеустойчивые и многоотавные злаки. Динамика изменения видового состава зеленого конвейера показала, что в двухкомпонентной злаковой смеси кострец (20) + пырейник (16 кг/га) участие костреца достигало 53,0\%, пырейника - 23,5\%, разнотравье - 23,5\% при урожайности 4,0 т/га. Участие костреца в бобово-злаковой травосмеси люцерна (8)+ к острец (10к г/га) достигало 43,4\%, люцерны $49 \%$, разнотравье - 7,55\%. Участие костреца составило до 45,5\% на трехкомпонентной бобово-злаковой травосмеси люцерна + кострец + донник, люцерны $49,5 \%$, разнотравья - 4,95\%, что способствовало получению урожая 4,0 т/га зеленой массы. Донник по своим биологическим особенностям полностью выпал из травостоя.

Изучение кормовой ценности, а также динамики химического состава кормовых растений показало, что они различаются между собой по содержанию питательного вещества. За годы исследований из приведенных данных видно, что наиболее высокое содержание сырого протеина по зеленому конвейеру отмечается из одновидовых злаковых посевов у овсяницы красной $18,2 \%$, при этом содержаниесырого жира - 2,9\%, сырой клетчатки - 32,0\%, сырой золы - 7,5\%, обменной энергии - 9,1 МДж, кормовых единиц - 0,66, переваримого протеина - 122 г в 1 кг сухого вещества.
Из бобово-злаковых травостоев наибольшее содержание сырого протеина отмечается у чистого посева люцерны (8 кг/га) - 19,0\%, при этом содержаниесырого жира - 2,7\%, сырой клетчатки - 29,7\%, сырой золы - 6,7\%, обменной энергии - 9,3 МДж, кормовых единиц - 0,70,п ереваримого протеина - 120 г в 1 кг сухого вещества (табл. 2). Сравнительно низкое содержание сырого протеина обеспечивает естественный травостой (контроль) - 9,0\%, при этом содержаниесырого жира - 2,3\%, сырой клетчатки - 35,8\%, сырой золы - 5,4\%, кормовых единиц - 0,57, переваримого протеина - 50,0 в 1 кг сухого вещества.

По экономической оценке сеяных травостоев при создании зеленого конвейера из злаковых травостоев высокий условно-чистый доход 5688 руб./га получен при посеве костреца безостого( 20 кг/га) +п ырейника( 16 кг/га), при этом стоимость продукции составила 120 00 руб./га, рентабельность - 90\%. Низкий выход кормовых единиц обеспечивает естественный травостой 912 с 1 га при стоимости продукции 4800 руб./га, вариант не рентабельный.

Из злаково-бобовых травосмесей высокую продуктивность обеспечили четырех- и пятикомпонентные травосмеси: люцерна (4 кг/га) + кострец (10 кг/га) + донник (8 кг/га) + пырейник(6 кг/га), люцерна (2 кг/га) + кострец

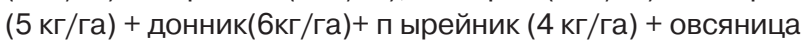


Таблица 2. Качество сеяных травостоев для создания зеленого конвейера (среднее за 2018-2020 гг.)

Table 2. Quality of seeded grass stands for creating a green conveyor (average for 2018-2020)

Видовой состав травосмесей (норма высева, кг/га)

1. Естественный травостой

2. Кострец безостый (20)

3. Пырейник сибирский (16)

4. Овсяница красная

5. Кострец (20) + пырейник (16)

6. Кострец (15) + овсяница (12)

7. Кострец + пырейник +о всяница

8. Люцерна желтая, сорт Якутская (8 кг/га)

9. Люцерна (8) + кострец (10)

10. Люцерна (6)+ к острец (15)+ д онник белый

11. Люцерна (6)+ п ырейник (12)+ д онник белый

12. Люцерна (4)+ к острец (10)+ донник+ п ырейник (8)

13. Люцерна (2) +кострец (5)+донник+пырейник (4)+о всяница
Абсолютно сухое вещество, \%

\begin{tabular}{|c|c|c|c|c|c|}
\hline протеин & жир & клетчатка & 0Э, МДж & корм. ед. & содержание ПП в 1 кг СВ, г \\
\hline 9,0 & 2,3 & 35,8 & 8,4 & 0,57 & 50 \\
\hline 15,0 & 2,8 & 32,6 & 9,0 & 0,65 & 103 \\
\hline 16,8 & 3,0 & 32,1 & 9,1 & 0,66 & 119 \\
\hline 18,2 & 2,9 & 32,0 & 9,1 & 0,66 & 122 \\
\hline 16,5 & 3,0 & 32,5 & 9,1 & 0,65 & 97 \\
\hline 16,4 & 2,9 & 32,6 & 9,0 & 0,65 & 109 \\
\hline 16,3 & 2,8 & 33,3 & 8,9 & 0,63 & 108 \\
\hline 19,0 & 2,7 & 29,7 & 9,3 & 0,70 & 120 \\
\hline 17,6 & 2,8 & 30,2 & 9,3 & 0,69 & 117 \\
\hline 17,3 & 2,8 & 30,7 & 9,2 & 0,68 & 116 \\
\hline 17,2 & 2,8 & 30,9 & 9,2 & 0,68 & 118 \\
\hline 17,2 & 2,8 & 30,5 & 9,2 & 0,69 & 117 \\
\hline 17,5 & 2,7 & 30,9 & 9,2 & 0,68 & 120 \\
\hline
\end{tabular}

(4 кг/га), выход кормовых единиц с 1г а составил 33813332, что обеспечивает получение условно-чистого дохода до 8388 руб./га при рентабельности 133\%.

\section{Выводы}

При организации зеленого конвейера из районированных многолетних трав на пойменных лугах в условиях Якутии максимальную урожайность из злаковых травосмесей обеспечивает кострец (20) + пырейник (16) - 4,0 т/га зеленой массы, что выше контроля на 2,4 т/га зеленой массы, при этом участие костреца достигало 53,0\%, пырейника - 23,5\%, разнотравье - 23,5\%. Урожайность чистого посева люцерны серповидной (8 кг/га) составила 4,5 т/га зеленой массы. Максимальную урожайность из бобово-злаковых травосмесей обеспечила двухкомпонентная смесь люцерна (8 кг/га) + кострец (10 кг/га) - 4,9 т/га зеленой массы. Участие люцерны в бобово-злаковой травосмеси люцерна (8) + кострец (10 кг/га) достигало до 49,0\%, костреца - 43,4\%, разнотравья - 7,55\%. Наиболее высокое содержание сырого протеина при создании зеленого конвейера из

\section{ЛИТЕРATУPA/REFERENCES}

1. Павлова С.А. Кормопроизводства в РС (Я): состояние и перспективы/ Павлова С.А., Пестерева Е.С., Захарова Г.Е // Кормопроизводство. -2018.-№5. - С. 5-8. /[Pavlova S. A., Pestereva E. S., Zakharova G. E. Kormoproizvodstva v RS (Ya): sostoyanie i perspektivy [Feed production in the RS (Ya): state and prospects]. -2018.-No. 5.-p. 5-8. (In Russ)]

2. Попов Н.Т., Пестерева Е.С., Павлова С.А. Производство сочного корма и создание зеленого конвейера в условиях Якутии /Кормление сельскохозяйственных животных и кормопроизводство.- Москва, 2013. - № 12.- С. 9-16. /[Popov N. T., Pestereva E. S., Pavlova S. A. Production of juicy feed and creation of a green conveyor in the conditions of Yakutia /Feeding of agricultural animals and feed production.- Moscow, 2013. - No. 12. - p. 9-16. (In Russ)]

3. Kshnikatkina, AN (Kshnikatkina, A. N.)[ 1 ] ; Timoshkin, OA (Ti-moshkin, O. A.)[ 2 ] ; Moskvin, Al (Moskvin, A. I.)[ 3 ] ; Timoshkina, OY (Timoshkina, O. Yu)[ 2 ] Penza State Agr Univ, 30 Bot Skaja St, Penza 440014, Russia, Competitive Ability and Biological Efficiency of Annual Mixtures.// Research Journal of Pharmaceutical Biological and Chemical Sciences. - 2018. Vol. 9. - p. 23-29

4. Lingorski, V (Lingorski, Vladimir) Res Inst Mt Stockbreeding \& Agr, 281 Vassil Levski St, Troyan 5600, Bulgaria Agricultural Academy - Bulgar-ia/Comparative study of sunflower late-spring mixtures for for-age production in a foothill region of Central Balkan mountains (Bulgar-ia)//Banats Journal of Bio-technology. - 2015.

Vol. 6. - 12. DOI: 10.7904/2068-4738-VI(12)-45

5. Конюхов Г.И. Земледелие Якутии /РАСХН. Сиб. Отд-ние. одновидовых злаковых посевов отмечается у овсяницы красной - 18,2\%, при этом содержание обменной энергии - 9,1 МДж, кормовых единиц -0,66, переваримого протеина - 122 г в 1 кг сухого вещества. Из бобово-злаковых травостоев наибольшее содержание сырого протеина обеспечивает люцерна (8 кг/га) - 19,0\%, при этом содержание обменной энергии - 9,3 МДж, кормовых единиц - 0,70, переваримого протеина - 120 г в 1 кг сухого вещества. При создании зеленого конвейера из злаковых травостоев высокий условно-чистый доход получен при посеве костреца безостого (20 кг/га) + пырейника (16 кг/га) - 5688 руб./га, при этом стоимость продукции -120 00 руб./га, рентабельность -90\%. Из бобово-злаковых травосмесей высокую продуктивность обеспечили четырех- и пятикомпонентные травосмеси: люцерна (4 кг/га) + кострец (10 кг/га) + донник (8 кг/га) + пырейник (6 кг/га), люцерна (2 кг/га) + кострец (5 кг/га) + донник (6 кг/га) + пырейник (4 кг/га) + овсяница (4 кг/га), выход кормовых единиц с 1 га составил до 3332, что обеспечивает получение условно чистого дохода до 8388 руб./га, при рентабельности 133\%.

Якут. НИИСХ. - Новосибирск, 2005. -360 с. /[Konyukhov G. I. Agriculture of Yakutia /RASKHN. Sib. Otd-nie. Yakut. Research Institute of agriculture. - Novosibirsk, 2005. -360 p. (In Russ)]

6. Система ведения сельского хозяйства в Республике Саха (Якутия) на период 2016-2020 годы. / Методическое пособие. - Якутский НИИСХ. - Якутск.2016. - 415 с. /[The system of agriculture in the Republic of Sakha (Yakutia) for the period 2016-2020. / Methodological guide. Yakut research Institute of agriculture. - Yakutsk. 2016 - - 415 p. (In Russ)]

7. Методические указания по проведению полевых опытов с кормовыми культурами. - М.: ВНИИ кормов, 1997. - 60 с. /[ Guidelines for conducting field experiments with forage crops. M.: Institute of feed, 1997. - 60C. (In Russ)]

8. Михайличенко, Б.П. Методическое пособие по агроэнергетической оценке технологий и систем ведения кормопроизводства / Б.П. Михайличенко, А.А. Кутузова, А.С. Шпаков. - М.: Россельхозакадемия, 2000. - 52 с. /[Mickle, B. P. Handbook on agroenergetics technology assessment and systems management of forage production / B. P. Mickle, A. A. Kutuzov, A. S. Shpakov. - M.: Russian Academy Of Agricultural Sciences, 2000. - 52 p (In Russ)]

9. Доспехов Б.А. Методика полевого опыта. -М.: Колос, 1985. - 347 c. / [Dospekhov B. A. Methodology of field experience. - M.: Kolos, 1985. - 347 p. (In Russ)]

10. Бенц, В.А. Полевое кормопроизводство в Сибири / В.А. Бенц, Н.И. Кашеваров, Г.А. Демарчук; РАСХН, Сиб. отд-ние; СибНИИ кормов. - Новосибирск, 2001. - 240 с. /[Benz, V. A. Field feed production in Siberia / V. A. Benz, N. I. Kashevarov, G. A. Demarchuk; RASKHN, Sib. otd-nie; SibNII kormov. - Novosibirsk, 2001. - 240 p. (In Russ)] 